\title{
Antiviral Activity of Vicoa indica Against Herpes Simplex Virus
}

\author{
A. M. Sabitha Rani ${ }^{1 *}$ and K. Murugesan ${ }^{2}$ \\ ${ }^{1}$ Faculty, Department of Biotechnology, Prince Shri Venkateshwara Arts and Science College, \\ Chennai - 600 073, India; sabitha_keerthi@yahoo.co.in \\ ${ }^{2}$ Centre for Advanced Studies in Botany, University of Madras, Chennai - 600 025, India; profkm1055@yahoo.com
}

\begin{abstract}
The aim of the present research was focused on the antiviral properties of Vicoa indica (L.) via in vitro approach. The aqueous and methanolic extracts from leaves, stems and roots of $V$. indica (Asteraceae) were tested against HSV - 1 replication. Among these extracts, aqueous extract of roots was found to have more potent inhibitory effect. The less concentration $(20 \mu \mathrm{g} / \mathrm{mL})$ of methanolic extracts was cytotoxic to vero cell lines. The used concentrations of aqueous extracts were $100-50 \mu \mathrm{g} / \mathrm{mL}$. We determined that extract obtained from root has higher antiviral effect, and it causes 100 per cent decrease of the virus at $\mathrm{IC}_{50}$ of 100 and $50 \mu \mathrm{g} / \mathrm{mL}$ respectively. Further research is needed to elucidate the active constituents of this plant may be useful in the development of new and effective antiviral agents.
\end{abstract}

Keywords: Asteraceae, Aqueous Extracts, Vicoa indica, HSV-1.

\section{Introduction}

Herpes simplex virus-1 (HSV-1) causes some of the most common viral infections in humans, such as mucocutaneous herpes infections, herpetic keratitis, herpetic encephalitis and neonatal herpes. Following primary infection, the particles of HSV-1 are carried by retrograde transport via sensory nerve endings to the ganglia, where the virions remain in a latent state until the development of reactivation by stimulation. It is conjectured that the recurrence of HSV-1 infection occurs by centrifugal spread of HSV -1 in axons from ganglia and by viral replication at the mucosal sites.

Acyclovir (ACV), a nucleoside analogue and selective anti-herpetic agent which has been widely used for therapy, inhibits the viral DNA replication through viral thymidine kinase, resulting in potent inhibition of viral DNA synthesis $[5,16]$. In a recent survey from Taiwan, the incidence of ACV-resistant HSV strains was found to be around 5 per cent among immunocompromised patients and 14 per cent among bone marrow transplant recipients [2]. This indicates the need for research of newer antiviral agents to treat such infections.

A number of compounds extracted from various species of higher plants have shown antiviral activity [3]. Examples included tannins [10], flavones [6, 17], and alkaloids [11] that displayed in vitro activity against numerous viruses. It has been suggested that selection of plant on the basis of ethnomedical considerations gives a higher hit rate than screening programmes of general synthetic products $[8,12]$. V. indica was been used in conditions like antifertility [7], antiviral [4], anti-inflammatory antipyretic $[1,14]$ and for bacterial infections $[13,18]$.

The active principle behind the antiviral activity of $V$. indica against HSV-1 has not yet been identified. Hence, the study was carried out to evaluate the antiviral property of both aqueous and methanolic extracts of leaves, stems and roots against HSV-1.

*Corresponding author:

A. M. Sabitha Rani (sabitha_keerthi@yahoo.co.in) 


\section{Materials and Methods}

\subsection{Plant Materials, Reagents, Cell Line and} Virus

The plant materials were collected from Arcot in and around Vellore District, Tamil Nadu, India and were authenticated by the Centre for Advanced Studies in Botany, University of Madras, Chennai, India where sample specimens were deposited. Extracts of different anatomical plants were prepared by using Soxhlet extraction unit (Borosil, Mumbai) as per the standard procedure [13].

Leaves, stems and roots of $V$. indica were shade dried and powdered. Fifty grams each of respective samples were soaked in $500 \mathrm{~mL}$ of double distilled water and $70 \%$ methanol separately. They were extracted with Soxhlet apparatus. The crude preparation was filtered through Whatman no.1 filter paper and dried at $50^{\circ} \mathrm{C}$. The drug was scrapped and stored at $4^{\circ} \mathrm{C}$.

Vero cells and HSV-1 required for the test are being maintained at the Department of Virology, King Institute of Preventive Medicine (KIPM), Guindy, Chennai - 600032.

Toxicity and antiviral assays were done using $1 \mathrm{gm}$ of leaves, stems and roots. Aqueous extracts were prepared and dissolved in $10 \mathrm{~mL}$ of sterile double distilled water to give a final concentration of $20 \mu \mathrm{g}-500 \mu \mathrm{g}$. It was filter sterilized using 0.45 micron syringe filter. Methanol extracts were weighed and dissolved in $10 \mathrm{~mL}$ of $0.5 \%$ DI Methyl Sulfoxide (DMSO) and filter sterilized using 0.45 micron syringe filter. The non toxic dilution of DMSO to Vero cell line was used to dissolve methanol extracts. The toxicity assay was performed using aqueous and methanol extracts $(20-500 \mu \mathrm{g})$ of $V$. indica in different anatomical parts.

HSV-1 was propagated in Vero cells and $10^{-7}$ TCID50/ $\mathrm{mL}$ was taken for antiviral assay. This study was carried out by mixing $1 \mathrm{ml}$ of drug ( $20-500 \mu \mathrm{g}$ concentration) and $1 \mathrm{ml}$ of different doses of virus as per procedure [19]. The mixture was incubated at different time intervals, viz. Immediate, 30, 60, 90 and $120 \mathrm{~min}$. The whole assays were observed for a period of 5 days. The cytopathogenic effect (CPE) was scored. The 50 per cent cytotoxic concentration (CTC50) was determined by the standard MTT assay [9] trypan blue dye exclusion method [15].

\subsection{Standard Antivirals}

Acyclovir (Sigma Chem. Co., St. Louis, USA) dissolved in distilled water and used as a standard antiviral drug
$(1 \mathrm{mg} / \mathrm{mL})$ with respect to test compounds at a concentration of $100 \mu \mathrm{g} / \mathrm{mL}$ to $20 \mu \mathrm{g} / \mathrm{mL}$.

\section{Results}

Antiviral activity of various concentration of acyclovir was carried out against HSV-1 (Table 1). Different anatomical parts of $V$. indica used in the traditional system of medicine collected from Arcot were tested for their antiviral activity. Aqueous root extract from the $V$. indica was found to have antiviral activity against HSV-1, at a concentration non toxic to the cell line (Vero). There was no difference in incubation periods (Table 2). The root aqueous extract exhibited detectable antiviral effect towards HSV-1 with an inhibitory concentration for 50 per cent $\left(\mathrm{IC}_{50}\right)$ of 100 and $50 \mu \mathrm{g} /$ $\mathrm{ml}$ respectively. The methanol extracts of $V$. indica showed

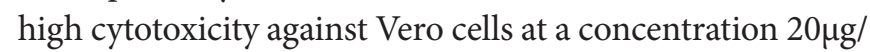
$\mathrm{ml}$. Hence, methanol extract of different anatomical parts were not used for antiviral assay. The results obtained by both CPE inhibition assay and virus yield assay were comparable.

\section{Discussion}

From the above results, it is inferred that aqueous extract of root at a concentration of $100 \mu \mathrm{g} / \mathrm{ml}$ exhibited strong activity against HSV-1. The inhibitory effect of drug and virus was independent of incubation period which showed that there was no difference in the anti HSV-1 activity [8].

Aqueous root extract of $V$. indica has a potential to have antiviral activity as compared to acyclovir drug treated virus control. Hence, the anti HSV-1 activity of root extract ( $V$. indica) should be investigated further for the identification of active principle responsible for the virucidal activity.

Future studies on these lines will pave a way for the treatment pattern of HSV-1 infection and potential exploitation of natural wealth for screening of antiviral principles present in the root aqueous extract of the plant.

\section{Acknowledgement}

The authors acknowledge the King Institute of Preventive Medicine, Chennai and the Centre for Advanced studies in Botany, University of Madras, Chennai, Tamil Nadu, India for lab facilities and WHO for financial support. 
Table 1. Antiviral activity of Acylovir

\begin{tabular}{lcccccccccc}
\hline \multicolumn{10}{c}{$\mathrm{IC}_{50} \mu \mathrm{g} / \mathrm{mL}$ (Acyclovir) } \\
\hline Virus & 0.10 & 0.20 & 0.30 & 0.40 & 0.50 & 0.60 & 0.70 & 0.80 & 0.90 & 100 \\
\hline HSV-1 & 0 & 0 & 0 & + & ++ & +++ & ++++ & ++++ & ++++ & ++++ \\
\hline
\end{tabular}

0 , no protection;,$+ 25 \%$ protection;,$++ 50 \%$ protection;,$+++ 75 \%$ protection;,$++++ 100 \%$ protection $\mathrm{IC}_{50}$ - Inhibitory Concentration for 50 percent of viruses

Table 2. Cytoxicity and antiviral activity of $V$. indica extracts

\begin{tabular}{|c|c|c|c|c|c|c|}
\hline \multirow{2}{*}{$\begin{array}{l}\text { Anatomical } \\
\text { parts used }\end{array}$} & \multirow[t]{2}{*}{ Extracts } & \multirow{2}{*}{$\begin{array}{c}\text { Cytotoxicity } \\
\mu \mathrm{g} / \mathrm{mL}\end{array}$} & \multirow{2}{*}{$\begin{array}{c}\text { Concentration } \\
\text { tested } \mu \mathrm{g} / \mathrm{mL} \\
\text { IC50 }\end{array}$} & \multicolumn{3}{|c|}{ CPE Inhibition assay } \\
\hline & & & & $2 \mathrm{TCID}_{50}$ & $10 \mathrm{TCID}_{50}$ & $100 \mathrm{TCID}_{50}$ \\
\hline \multirow[t]{2}{*}{ Leaves } & Aqueous & 300 & 100 & 0 & 0 & 0 \\
\hline & Methanol & 20 & 15 & 0 & 0 & 0 \\
\hline \multirow[t]{2}{*}{ Stems } & Aqueous & 300 & 100 & 0 & 0 & 0 \\
\hline & Methanol & 20 & 15 & 0 & 0 & 0 \\
\hline \multirow[t]{3}{*}{ Roots } & Aqueous & 300 & 100 & ++++ & ++++ & ++++ \\
\hline & & & 50 & ++++ & ++++ & ++++ \\
\hline & Methanol & 20 & 15 & 0 & 0 & 0 \\
\hline
\end{tabular}

0 , no protection;,$+ 25 \%$ protection;,$++ 50 \%$ protection;,$+++ 75 \%$ protection;,$++++ 100 \%$ protection CPE - Cytopathic Effect

$\mathrm{IC}_{50}$ - Inhibitory Concentration for 50 percent of viruses

\section{References}

1. Alam M, Susan T et al. (1992). Anti-inflammatory and antipyretic activity of vicolides of Vicoa indica DC, Indian Journal of Experimental Biology, vol 30(1), 38-41.

2. Callier L, and Oxford J (1993). Human Virology: a text book for students of Medicine, Points of action of antivirals in the virus life cycle Dentistry and Microbiology, Oxford University Press, 310.

3. Chiang L C, Cheng H Y et al. (2003). In vitro antiherpes simplex viruses and anti-adenoviruses activity of twelve traditionally used medicinal plants in Taiwan, Biological and Pharmaceutical Bulletin, vol 26(11), 1600-1604.

4. Chowdhury B L, Hussaini F A et al. (1990). Antiviral constituents from Vicoa indica, International Journal of Crude Drug Research, vol 28, No. 2, 121-124.

5. Cinatl J, Vogel U et al. (1997). Antiviral effects of 6-diazo-5 -oxo-L-norleucin on replication of Herpes Simplex Virus type-1, Antiviral Research, vol 33(3), 165-175.

6. De Rodriguez D J, Chula J et al. (1990). Search for in vitro antiviral activity of a new isoflavone glycoside from Vlex europeus, Planta Medica, vol 50, 59-62.
7. Dhall K, and Dogra M (1988). Phase I and II clinical trials with Vicoa indica (Banjauri), a herbal medicine, as an antifertility agent, Contraception, vol 37(1), 75-84.

8. Ferraro G, Broussalis A et al. (1992). Argentine medicinal plants: antiviral screening, Acta Horticulturae, vol 306, 239-244.

9. Francis D, and Rita L (1986). Rapid colorimetric assay for cell growth and survival: modifications to the tetrazolium dye procedure giving improved sensitivity and reliability, Journal of Immunological Methods, vol 89(2), 271-277.

10. Fukuchi K, Sakagarmi H et al. (1989). Inhibition of herpes simplex virus infection by tannins and related compounds, Antiviral Research, vol 11 (5-6), 285-297.

11. Hu J M, and Hsiung G D (1989). Evaluation of new antiviral agents I: in vitro prospectives, Antiviral Research, vol 11(5-6), 217-232.

12. Hudson J B (1990). Antiviral compounds from plants, Natural terpenoids as messengers, CRC Press, Boca Raton, Florida, 382.

13. Kesavan S, Devarajan N et al. (2007). Antibacterial, Preliminary phytochemical and pharmacognostical screening on the leaves of Vicoa indica (L.) DC, Iranian Journal of Pharmacology \& Therapeutics, vol 6(1), 109-113. 
14. Krishnaveni M, Suja V et al. (1997). Anti-inflammatory and analgesic actions of 4,5,6-trihydroxy-3'7-dimethoxy flavonefrom Vicoa indica DC, Indian Journal of Pharmacology, vol 29(3), 178-181.

15. Moldeus P, Hogberg J et al. (1978). Methods in enzymology, Trypan blue dye exclusion method, vol 52, Academic Press, New York, 60-71.

16. Sibrack C D, Gutman, L T (1982). Pathogenicity of acyclovir resistant herpes simplex virus type 1 from an immunodeficient child, The Journal of Infectious Diseases, vol 146(5), 673-682.
17. Spedding G, Ratty A et al. (1989). Inhibition of reverse transcriptases by flavonoids, Antiviral Research, vol 12(2), 99-110.

18. Vanden Berghe D A, and Vlietinek A J (1991). Screening methods for antibacterial and antiviral agents from higher plants, Hostettmann K (Ed.), Methods in biochemistry, vol 6, Academic Press, London, 47.

19. Vijayan P, Raghu Cet al. (2004). Antiviral activity of medicinal plants of Niligiris, The Indian Journal of Medical Research, vol 120(1), 24-29. 